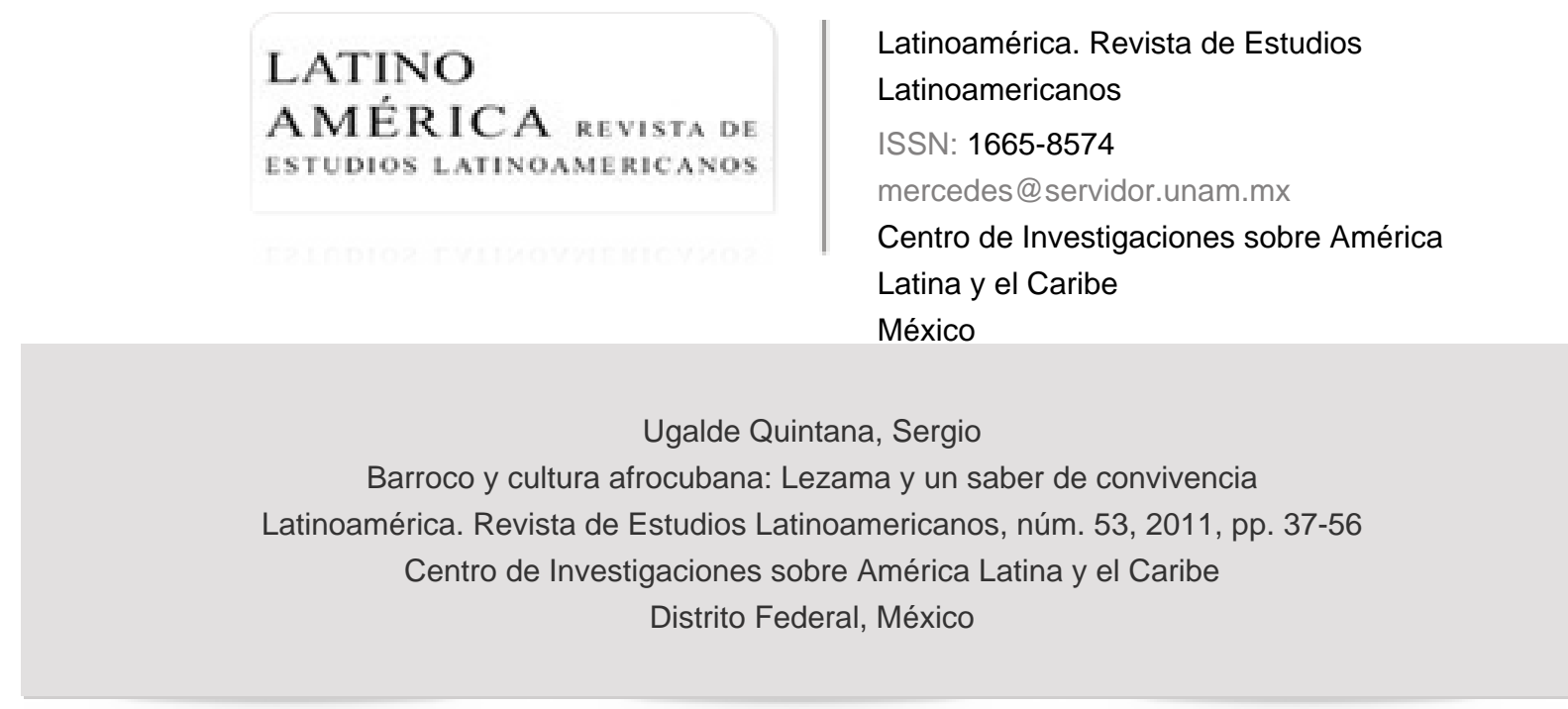

Disponible en: http://www.redalyc.org/articulo.oa?id=64021405003

- Cómo citar el artículo

- Número completo

- Más información del artículo

- Página de la revista en redalyc.org

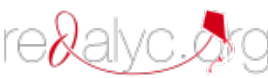

Sistema de Información Científica

Red de Revistas Científicas de América Latina, el Caribe, España y Portugal Proyecto académico sin fines de lucro, desarrollado bajo la iniciativa de acceso abierto 


\section{Barroco y cultura afrocubana: Lezama y un saber de convivencia}

Sergio Ugalde Quintana*

ResuMEN: En este artículo se analizan distintos momentos de la relación de José Lezama Lima con la cultura afrocubana. De la visión crítica de la poesía negrista en los años treinta, el poeta pasó, hacia finales de su vida, a una integración simbólica de algunos elementos de la cultura negra e insular. En ese tránsito, desempeña un papel importante su relación amistosa con la escritora y antropóloga cubana Lydia Cabrera. Sin embargo, el término que da sentido a este proceso de incorporación cultural es el de barroco.

PalabRaS ClavE: José Lezama Lima, Barroco, Negrismo, Cultura afrocubana.

ABSTRAC: In this article we analize different moments of the relationship of José Lezama Lima with Afro-Cuban culture. From his critical view of the "negrist" poetry in the thirties, the poet switch, towards the end of his life, to a symbolic integration of some elements of black and insular culture. In this transition, plays an important role his friendship with Cuban writer and anthropologist Lydia Cabrera. However, the term that gives meaning to this process of cultural incorporation is the baroque.

Key words: José Lezama Lima, Baroque, Negrism, Afro-cuban Culture.

Facultad de Filosofía y Letras-unam (sugalde@hotmail.com). 
LA CASA Y EL TEXTO

U

a de las fotografías más famosas de José Lezama Lima muestra al poeta y narrador cubano sentado en su estudio de Trocadero 162 en La Habana Vieja. La imagen, a primera vista, podría ser la biblioteca de cualquier intelectual hispanoamericano de mediados del siglo xx. Sin embargo, si observamos con detenimiento podemos comenzar a distinguir los trazos personales y significativos del decorado. En la parte alta de las paredes, ausente de estanterías y de libros, se muestra por lo menos una docena de cuadros de distintos pintores: entre ellos se alcanza a distinguir el retrato de una mujer realizado por René Portocarrero, un cuadro de Mariano Rodríguez, uno más de Arístides Fernández, los tres pintores fueron amigos y colaboradores de Lezama durante los años treinta, cuarenta y cincuenta en la Cuba del siglo xx. En la parte media del muro hay una mascarilla totonaca, seguramente adquirida por Lezama en 1949 durante su viaje a México, junto a ella, hay un platón de cerámica china. Sobre los estantes de libros se encuentran varias figurillas prehispánicas, hay vasijas con decoraciones griegas, una reproducción en miniatura de Nefertiti, estatuillas de Lao-Tsé, Confucio, Narciso, Cupido, dracmas griegos y una copa de plata mexicana; en medio de esa pared, vigilando el caos de los objetos, está un retrato de José Martí, el escritor e independentista cubano. Los libros se alzan sobre la mesa como una muralla que protege al dueño de todos estos objetos. Lezama Lima mira a la cámara sentado en medio de ese universo caótico. La impresión que nos deja este espacio, que Severo Sarduy definió como un "amontonamiento de cuadros y muebles coloniales", 1 no pasaría de ser una imagen pintoresca y algo anacrónica ${ }^{2}$ si no fuera porque en él se encuentra una metáfora del universo textual de las obras lezamianas. En los ensayos, las novelas y los poemas de Lezama conviven, como en el estudio de su casa, fragmentos de la cultura china, egipcia, griega, precolombina, afrocubana en medio de referencias a Proust, Thomas Mann, Platón, Góngora, Quevedo y, por supuesto,

1 Severo Sarduy, "Paradiso y la cuestión de la novela", en Antología, México, FCE, 2000, p. 147.

2 Enrique Pérez Cristóbal, "La imagen anacrónica. Alrededores de Lezama Lima", en La Habana Elegante, primavera-verano, 2010. En http://www.habanaelegante.com/Spring_Summer_2010 /Dicha_PerezCristobal.html (fecha de consulta: 6 de julio, 2010). 
Goethe. El espacio de la biblioteca de Lezama es a un mismo tiempo un espejo de la dinámica textual de sus obras. El cuarto de estudio se transforma en un espacio-texto. La morada se vuelve un signo de la escritura.

\section{EL BARROCO}

En 1937, a la edad de 27 años, Lezama publicó: Muerte de Narciso, su primer poema donde se nota, además de la influencia de Góngora y Valéry, un universo imaginario que hace convivir mitos y símbolos de distintos referentes culturales. El primer verso del poema muestra a una deidad griega en el ámbito egipcio: "Dánae teje el tiempo dorado por el Nilo". ${ }^{3}$ La densidad del proyecto poético de Lezama no sólo se manifestaba en el complejo sistema de referencias cultas y eruditas, en el resumen de una amplia red de lecturas, sino en la manera tan natural de hacer convivir simultáneamente elementos mitológicos de lo más diverso. Ese verso inaugural de Muerte de Narciso, además de enigmático, es el comienzo de una carrera literaria que muchos han identificado con el término "barroco". ${ }^{4}$ Ciertamente, Lezama creció y se formó en un ambiente que, después de los movimientos de vanguardia, hizo una lectura vital y novedosa del ba-

3 José Lezama Lima, "Muerte de Narciso", en Verbum, núm. 2, julio-agosto, 1937, p. 29. Muchos años después, en 1976, el poeta aseguró sobre esta obra: "La Muerte de Narciso me hizo un poco conocido, conocido como desconocido, $[\ldots]$. Se publicó $[\ldots]$ en una revista que yo hacía en la Universidad que se llamaba Verbum. Ahí se ven ya las influencias que predominan en mí siendo casi adolescente. La influencia de don Luis de Góngora, mi maestro, la influencia de Stefan Mallarmé, la influencia de Paul Valéry, la influencia de los simbolistas franceses, del neogongorismo español [...]. El poema, pudiéramos decir, es una despedida de mi adolescencia $[\ldots]$ tiene en germen como toda la posibilidad del desarrollo de mi obra futura". Iván González Cruz [ed.], Diccionario, vida y obra de José Lezama Lima, Valencia, Generalitat Valenciana, 2000, p. 320.

4 Sobre la relación entre Lezama y el barroco hay una abundante bibliografía; menciono sólo algunos trabajos: Severo Sarduy, "Dispersión, falsas notas / Homenaje a Lezama", en Eugenio Suárez Galbán [ed.], Lezama Lima el escritor y la crítica, Madrid, Taurus, 1987, pp. 116-140; Severo Sarduy, Barroco, Buenos Aires, Sudamericana, 1974; Roberto González Echevarría, "Apetitos de Góngora y Lezama", en Revista Iberoamericana, núm. 41, 1975, pp. 479-491; Roberto González Echevarría, "Lezama, Góngora y la poética del mal gusto", en Hispania, núm. 84, 2001, pp. 428-440; Irlemar Chiampi, "El barroco en el ocaso de la modernidad", en Barroco 
rroco hispánico. Mientras el modernismo y las vanguardias hispanoamericanas habían encontrado en la literatura de los Siglos de Oro una fuente de renovación retórica, Lezama y su generación, por el contrario, vieron en el barroco no sólo un universo artístico antiguo, sino una forma de vida actual y moderna; un ethos, para hablar en el sentido de Bolívar Echeverría. ${ }^{5}$

En sus primeros ensayos, Lezama indagó sobre la relación de la cultura nacional cubana con los diferentes universos culturales. En un diálogo que entabló con el escritor español Juan Ramón Jiménez, hacia 1937, el poeta de La Habana definió la insularidad como una sensibilidad mítica: "Me gustaría que la sensibilidad insular se mantuviese sólo con la mínima fuerza secreta para decidir un mito". El mito que buscaba Lezama era el de una sensibilidad y expresión que abarcara todas las tradiciones. En esos mismos años, en la editorial de Espuela de Plata, su segunda revista, Lezama definió su programa cultural para la Isla con las siguientes palabras: "La ínsula distinta en el Cosmos, o lo que es lo mismo, la ínsula indistinta en el Cosmos". ' La mejor estética para manifestar ese universo de universos, esa disolución del cosmos en la Isla, esa confluencia de aportes culturales diferentes, fue, sin duda, el barroco:

La generación de pintores del 25 nació bajo la égida del esprit nouveau, la generación del 40 [hizo] peculiar detenimiento, en pintura y poesía, en las mani-

\footnotetext{
y modernidad, México, FCE, 2000, pp. 17-41; Julio Ortega, "De Lezama Lima a Severo Sarduy: el barroco latinoamericano", en Identità e metamorfosi del Barroco Ispanico, Nápoles, Guida, 1987, pp. 199-212; Juan Goytisolo, "La metáfora erótica: Góngora, Joaquín Belda y Lezama Lima", en Revista Iberoamericana, núm. 42, 1976, pp. 157-175; Carmen Ruiz Barrionuevo, "Góngora y Garcilaso en los comienzos de Lezama Lima: el secreto de Garcilaso", en Las relaciones literarias entre España e Iberoamérica. XXIII Congreso Internacional de Literatura Iberoamericana, Madrid, Instituto de Cooperación Iberoamericana, Facultad de Filología de la Universidad Complutense de Madrid, 1987, pp. 537-543; Ester Gimbernat de González, "La curiosidad barroca", en Coloquio Internacional sobre la obra de José Lezama Lima, Fundamentos, Madrid, 1984, vol. 1, pp. 59-66.

5 Sobre la idea del "Ethos barroco", véase Bolívar Echeverría, La modernidad de lo barroco, México, Era, 1998.

6 José Lezama Lima, "Coloquio con Juan Ramón Jiménez" [1937], en Obras completas, México, Aguilar, 1977, vol. II, p. 51.

7 José Lezama Lima, "Razón que sea", en Espuela de Plata, núm. 1, agosto-septiembre, 1939, p. 1.
} 
festaciones estilísticas del barroco [...]. En realidad, esa apreciación del barroco era una vuelta al planteamiento estilístico de lo que debía ser el arte americano en función de arte universal. Es decir, un rico material cuantitativo, tomado de todos los aportes $[\ldots]$ que laboraba sobre la forma $[. .$.$] . Esa síntesis [. .$.$] es ne-$ cesaria para integrar el barroco. ${ }^{8}$

La génesis de la idea de lo barroco en Lezama debe remitirse al ámbito intelectual de las primeras décadas del siglo xx. En esos años, las discusiones, inauguradas por los célebres libros de Heinrich Wölfflin Renaissance und Barock (1888) y Kunstgeschichtliche Grundbegriffe (1915), giraban en torno a los redescubrimientos de una estética que había sido relegada durante todo el siglo XIX. Los trabajos históricos y teóricos en torno al concepto del barroco inundaron el universo letrado de los años veinte y treinta del siglo pasado. Lezama, quien había nacido en 1910, siguió la mayoría de esas polémicas en las traducciones de los libros que, bajo la guía intelectual de José Ortega y Gasset, las editoriales españolas Espasa-Calpe y Revista de Occidente hicieron durante esa época.

En el universo ensayístico de Lezama, que se consolidó hacia los años treinta y cuarenta del siglo xx, pueden distinguirse claramente dos ideas directrices sobre el fenómeno barroco. Por un lado, la noción de un estilo histórico que, en el mundo español, marcó una parte de la literatura y el arte de los Siglos de Oro $y$, por otro, la idea de que ese fenómeno artístico era resultado de una matriz cultural. Las reflexiones lezamianas sobre el barroco, dispersas en varios de sus textos, se dividen pues entre una lectura estilística y una culturalista.

Quizá el primer texto donde Lezama utiliza el concepto de barroco, para definir un estilo asociado a un momento estelar de la literatura hispánica, sea el ensayo "El secreto de Garcilaso", publicado en la revista Verbum, en el año de 1937. Ahí, Lezama estableció los paralelos y las continuidades entre dos figuras fun-

8 González Cruz, op. cit., p. 41.

9 Los libros sobre el barroco, fundadores de ese ambiente, fueron traducidos por ambas editoriales: Heinrich Wölfflin, Conceptos fundamentales de la bistoria del arte, trad. de José Moreno Villa, Madrid, Espasa-Calpe, 1924; Wilhelm Worringer, La esencia del estilo gótico, trad. de Manuel García Morente, Buenos Aires, Revista de Occidente, 1942, y Werner Weisbach, El barroco: arte de la contrarreforma, trad. de E. Lafuente Ferrari, Madrid, Espasa-Calpe, 1942. 
dadoras de la poesía del Renacimiento y del Barroco español: Garcilaso de la Vega y Luis de Góngora. Apenas un año antes, en 1936, se había conmemorado el cuarto centenario de la muerte de Garcilaso. Lezama, quien por su juventud, no había participado de la celebración gongorina de 1927, encontró en esta fecha, once años después, la oportunidad de valorar no sólo al poeta de Toledo, sino también al autor de Las soledades. La idea central del ensayo era un tanto provocadora: Góngora no era el representante de un barroco teológico-poético, sino un continuador de los hallazgos garcilasianos, en otras palabras, un barroco posrenacentista: "Góngora es sin duda no un barroco, en el sentido de ser arrastrado por una fuerza poético-religiosa que nace sin resignarse a constituirse en expresión, como familia de sirenas que pudiesen vivir sin respirar. Es un barroco posrenacentista". ${ }^{10} \mathrm{~A}$ lo largo de todo el ensayo, Lezama se rebela contra el postulado de Wilhelm Worringer de que lo barroco es la degeneración de lo gótico. La poesía de Garcilaso, asegura Lezama, no es una obra gótica que se degenere, sino el "centro del cual van a surgir Lope y Góngora". ${ }^{11}$ Una y otra vez Lezama contrapone las expresiones poéticas de Garcilaso y de Góngora para establecer un universo de continuidades y paralelismos entre el Renacimiento y el Barroco: "Mientras Góngora endulza su estructura, abrillanta su esqueleto y enrojece al vivo su connatural viveza que aduerme voluntariamente un solo ojo, Garcilaso orgánicamente resuelve la antinomia Medioevo-Renacimiento, Toledo-Roma". ${ }^{12}$ En los señalamientos lezamianos de ese ensayo hay una obsesión constante por definir los estilos que, a su vez, estructuran dos épocas históricas.

En ese mismo sentido, varios años después, en 1951, Lezama dedicó un ensayo completo a Luis de Góngora. En ese texto, el poeta de La Habana volvía a establecer paralelos y diferencias entre dos formas literarias, en esta ocasión ambas barrocas: Calderón de la Barca y Góngora. La solución era inequívoca: cada uno de ellos representaba un estilo particular del barroco español: "el ba-

${ }^{10}$ José Lezama Lima, "El secreto de Garcilaso" [1937], en Obras completas II, México, Aguilar, 1977, p. 16.

${ }^{11}$ Ibid., p. 15.

${ }^{12}$ Ibid., p. 41. 
rroco concentrado e incandescente de Góngora [ ... ] y el barroco curvo, suelto y lánguidamente sucesivo de Calderón". ${ }^{13}$ En ese ensayo Lezama habla de la peculiaridad estilística de la obra gongorina: de los objetos en su poesía, de la luminosidad verbal, de la luz del sentido de sus versos, de la sensualidad poética, del mundo como un banquete, de la festividad sensorial. Todos esos señalamientos, le sirven para asegurar que la poesía de Góngora carece de "la noche oscura de san Juan". En El Polifemo de Góngora, Lezama encuentra "un barroco neptúnico, típicamente renacentista". Nuevamente, en este ensayo se configura un estilo y una forma artística muy peculiar de un momento histórico.

Algo distinto sucede cuando Lezama se acerca al barroco americano. En este caso, la pregunta por el estilo sólo es relevante en tanto que revela la complejidad del universo cultural americano. Se trata no de un acercamiento estilístico sino culturalista. Lezama, en este caso, indaga por una expresión que funda, a un mismo tiempo, una cultura. La lectura culturalista del barroco en Lezama ya se anunciaba de manera precisa en un ensayo de 1948, sobre el pintor Roberto Diago. Ahí, el poeta hablaba de la importancia de valorar el barroco hispánico como "un humus fecundante que evaporaba cinco civilizaciones". ${ }^{14}$ Si el barroco hispánico era una síntesis de cinco civilizaciones; el barroco americano era una expresión más compleja pues, al pasar el océano y tomar asiento en un nuevo continente, incorporaba, por lo menos, otros dos universos imaginarios: el indígena y el negro. El paso siguiente era casi obvio; el barroco americano representaba dos confluencias: la hispano-indígena y la hispano-negroide. Lezama, en unas conferencias de 1957, encontró en dos figuras del arte virreinal esas manifestaciones sincréticas: Kondori y Aleijadinho. El primero, un supuesto artista incaico, ${ }^{15}$ representaba una gran hazaña barroca del nuevo continente: la inclusión del universo indígena en la forma europea:

13 José Lezama Lima, "Sierpe de Luis de Góngora" [1951], en Obras completas II, México, Aguilar, 1977, p. 193.

${ }^{14}$ José Lezama Lima, "En una exposición de Roberto Diago" [1948], en ibid., p. 745.

${ }^{15}$ Al parecer la existencia de un escultor indígena llamado Kondori siempre fue dudosa. Todo indica que se trataba de una obra colectiva. Lezama, al construir su imagen del artista andino, 
[Kondori] Había estudiado con delicadeza y alucinada continuidad las plantas, los animales, los instrumentos metálicos de su raza, y estaba convencido de que podían formar parte del cortejo de los símbolos barrocos en el templo [ . . . ] igualaba la hoja americana con la trifolia griega, la semiluna incaica con los acantos de los capiteles corintios, el son de los charangos con los instrumentos y las renacentistas violas de gamba. Ahora gracias al heroísmo y revivencia de sus símbolos, precisamos que podemos acercarnos a las manifestaciones de cualquier estilo sin acomplejarnos ni resbalar, siempre que insertemos allí los símbolos de nuestro destino y la escritura con que nuestra alma anegó los objetos. ${ }^{16}$

Además de incorporar el imaginario indígena, el barroco americano proyectaba también la cultura afroamericana. La obra escultórica de Aleijadinho, un artista mulato de Minas Gerais, era ejemplo de esa compleja convivencia cultural:

Su madre era una negra esclava. Su padre un arquitecto portugués. Ya maduro el destino lo engrandece con la lepra, que lo lleva a romper con una vida galante y tumultuosa, para volcarse totalmente en sus trabajos de piedra. Con su gran lepra, que está también en la raíz proliferante de su arte, riza y multiplica, bate y acrece lo hispánico con lo negro. ${ }^{17}$

De esta manera, Kondori y Aleijadinho creaban una obra que sintetizaba el estilo barroco peninsular con los universos culturales y simbólicos de los mundos indígena y afroamericano. En ambos casos se trataba de una subversión, no sólo estilística sino cultural del código artístico. Para Lezama, el barroco ameri-

como la de Aleijadinho, toma muchos datos del libro de Ángel Guido, Redescubrimiento de América en el arte [1941], Bueno Aires, El Ateneo, 1944. Sobre este tema, Ester Gimbernat de González asegura: "Lo paradójico es que estudios posteriores han invalidado las teorías de Guido sobre la iglesia de Potosí y el indio Condori. Mario Buschiazzo dice que lo de Condori "no se basaba en documento alguno; era una simple conjetura, o mejor dicho, fantasía, cuyo valor diluía al saberse que Condori es el más popular de los apellidos quechuas [...] Guido aceptó sin titubeos lo que dijera Subieta Sagárnaga y levantó todo el andamiaje de su teoría indigenista sobre ese nombre indocumentado". Esther Gimberat de González, "La curiosidad barroca", en Coloquio Internacional sobre la Obra de José Lezama Lima, Madrid, Fundamentos, 1984, vol. 1, pp. 61 y 62.

${ }^{16}$ José Lezama Lima, La expresión americana [1957], México, FCE, 1998, p. 104

${ }^{17}$ Ibid., p. 106. 
cano era un arte, no de la contrarreforma -rígida y jesuítica- como aseguraba Weisbach, sino de la contraconquista: la forma europea adquiría, con la inclusión de las culturas americanas, un carácter diferente y distinto. El barroco americano se volvía, entonces, una rebelión.

La idea del barroco como confluencia cultural nos remite inmediatamente a un término acuñado en la Cuba de los años veinte y treinta: transculturación. Por la misma época en que Lezama comenzó a valorar la estética barroca como un programa cultural y un proyecto de vida, el antropólogo cubano Fernando Ortiz difundió en conferencias y ensayos una idea central para las posteriores reflexiones sobre la cultura insular. Según Ortiz, nadie en la cultura cubana preservaba intacta su identidad cultural. Todos, tanto la población blanca, como la china, la africana, la indígena, la mestiza, aportaban algún elemento para la configuración multifacética de la nacionalidad cubana. El antropólogo utilizó una metáfora culinaria para referirse a este proceso de convivencia cultural: el ajiaco, el plato nacional cubano donde se mezclan todos los ingredientes. La nacionalidad cubana, según la opinión de Ortiz, era el producto de un ajiaco cultural donde todos los aportes, inmigrados y autóctonos, convivían y se interrelacionaban en un mismo espacio-tiempo. ${ }^{18}$ Hacia 1940, Fernando Ortiz maduró sus opiniones en su libro Contrapunteo cubano del tabaco y del azúcar. El ajiaco cultural, en ese libro, fue llamado por Ortiz: transculturación. Es muy difícil no ver el vínculo entre la idea lezamiana de barroco y la metáfora del ajiaco transcultural de Ortiz. ${ }^{19}$

El barroco lezamiano, como la República transcultural de Ortiz, responde a su entorno insular. La escenificación barroca del cuarto de Lezama, con fragmentos de la cultura china, americana, egipcia y griega, es una metáfora de sus textos, pero también una alegoría de la isla del Caribe. No se trata de exotismo,

${ }^{18}$ Fernando Ortiz, "Los factores humanos de la cubanidad" [1940], en Etnia y sociedad, La Habana, Ciencias Sociales, 1993.

${ }^{19} \mathrm{Al}$ respecto dice César Augusto Salgado: "Lezama Lima's reinvention of the baroque as New World hybrid is thus indebted to the theory of 'transculturation' postulated by his fellow countryman Fernando Ortiz in Cuban Counterpoint: Tobacco and Sugar [1947]. With 'transculturation,' Ortiz did not consider colonial contact between 'advanced' European and 'primi- 
sino de indagación por los distintos estratos que fundan las realidades cubanas, insulares y caribeñas. La escenificación fragmentaria y compleja de diversas culturas en la fotografía de Lezama, y en sus propios textos, sólo se puede entender dentro de la dinámica espacial - territorial e imaginaria - donde fueron representados, concebidos y escritos: es decir, una isla del Caribe. La isla de Cuba, como el archipiélago caribeño, es un espacio de confluencia de todos esos universos imaginarios. De Fernando Ortiz a Benítez Rojo, de Dereckt Walcott a Ottmar Ette, de Aimé Césaire a René Depestre, de Edouard Glissant a Kamau Brathwaite, de Margarita Mateo a Arcadio Díaz Quiñones, la reflexión sobre la confluencia cultural, poblacional, imaginaria, literaria y mítica de distintos campos culturales se ha vuelto, a la hora de hablar del Caribe, un paradigma, en el sentido de Giorgio Agamben. ${ }^{20}$ En el Caribe hispánico, anglófono o francófono, conviven poblaciones amerindias con proyectos occidentales, culturas africanas desarraigadas por la esclavitud con comunidades china e hindúes (coolies) importadas a fines del siglo xIx. Poblaciones de cuatro continentes -América, Europa, África y Asia- conviven en un espacio fragmentado, fractal y fracturado, por distintas lenguas en el archipiélago caribeño. La confluencia poblacional, como signo de convivencia forzada y voluntaria, marca los ritmos culturales y literarios de los escritores caribeños. Por eso, Derek Walcott, al recibir el premio Nobel de Literatura en 1992, se refirió a su realidad caribeña como un espacio donde conviven los fragmentos de la memoria cultural de Asia, África, Europa y América:

tive' indigenous societies in America as a process of erasure of the 'weak' and assimilation into the 'strong'; looking at how Spanish colonists adopted taino (Caribbean indigenous peoples of Arawak descent) tobacco rituals and consumption that added an alien, 'demoniac' dimension to their Catholic mores and behavior, Ortiz argues that so-called extinct cultures always survive by infecting and refashioning the symbols of the dominating culture (1947). This is what the New World transculturation of the baroque in Lezama Lima's theory allows: the survival of Otherness piggy- backing on the unsuspecting signs of Empire". César Augusto Salgado, "Hybridity in New World Baroque Theory", en The Journal of American Folklore, vol. 112, núm. 445, 1999, p. 324 .

${ }^{20}$ Giorgo Agamben, Signatura rerum. Sobre el método, trad. de Flavio Costa y Mercedes Ruvitoso, Barcelona, Anagrama, 2010, p. 40. El paradigma es una forma analógica de conocimiento no hay en él un origen, todo fenómeno es el origen. 
I was entitled like any Trinidanian [... ] to the feast of Husein, to the mirrors and crêpe-paper temples of the Muslim epic, to the Chinese Dragon Dance, to the rites of that Sephardic Jewish synagogue $[. .$.$] the love that reassembles the frag-$ ments is stronger than that love which took its symmetry for granted when it was whole $[\ldots]$. It is such a love that reassembles our African and Asiatic fragments $[\ldots]$. This gathering of broken pieces is the care and pain of the Antilles [...]. Antillean art is the restoration of our shattered histories, our shards of vocabulary, our archipielago becoming a synonym for pieces broken off from the original continent. ${ }^{21}$

Como cualquier nativo de Trinidad yo tenía [...] acceso a la fiesta de Husein, a los espejos y los templos de papel crepé de la épica musulmana, al baile del dragón chino, a los ritos de la sinagoga sefardí [...] el amor que reúne los fragmentos es más fuerte que el amor que dio por sentada la simetría cuando estaba intacta $[\ldots]$. Es este amor el que reúne nuestros fragmentos africanos y asiáticos (americanos y occidentales). [...] Esta labor de unir los pedazos rotos es el cariño y dolor de las Antillas [... ]. El arte antillano es la restauración de nuestras historias rotas $[\ldots]$ y nuestro archipiélago se convierte en sinónimo de fragmentos desgajados de su continente original.

Lezama, en su gusto, en apariencia estrafalario y exótico, por universos culturales tan disímbolos, en realidad pone en escena un movimiento cultural subyacente: la Isla como escenario transcultural de distintas imaginaciones. La imagen del erudito exótico, visto desde esta perspectiva, toma otras dimensiones. El proyecto del arte en Walcott, como un restablecimiento de los fragmentos, y la idea del barroco en Lezama, como un estilo que absorbe todos los estilos, sólo pueden entenderse como una forma de la convivencia del Caribe. Un ejemplo puede ilustrar el proceso de incorporación lezamiano de los imaginarios insulares.

${ }^{21}$ Dereck Walcott, "The Antilles: fragments of Epic Memory" [1992], en What the Twilight says, Londres, Faber and Faber, 1998, p. 69. 


\section{LA CULTURA AFROCUBANA}

Cuando Lezama comenzó a publicar sus primeras obras, el espectro poético de la isla de Cuba se dividía esencialmente en dos grupos: por un lado, los seguidores del arte puro, representados por Mariano Brull, y, por el otro, los vanguardismos sociales, donde figuraba la poesía negrista, con poetas como Ramón Guirao, Emilio Ballagas y Nicolás Guillén. Un ambiente nacionalista enmarcaba ambos proyectos estéticos. En algunos sentidos, Lezama se sentía más cercano a las propuestas del arte puro, al estilo de Valéry, aunque nunca dejó de manifestar cierto recelo ante la idea del cartesianismo poético. ${ }^{22}$ Algo indudable fue que en los años treinta, Lezama criticó abiertamente la propuesta del negrismo literario. En su "Coloquio con Juan Ramón Jiménez", publicado en 1937, por ejemplo, aseguraba:

Entre nosotros, la poesía, cuyo principal hallazgo ha sido la incorporación de la sensibilidad negra y, más frecuentemente, la incorporación del vocablo onomatopéyico, se resiente de haber estado de espaldas [... ] a lo que debe responder toda poesía [... . Más claro, un elemento percutible, en su más elemental forma musical no produce más que una poesía anecdótica. ${ }^{23}$

Las soluciones poéticas que Lezama buscaba, en esos momentos, nada tenían que ver con la inclusión de la cultura afrocubana. En ese mismo ensayo, páginas adelante, el poeta arremetía contra la idea de un arte mestizo:

Una realidad étnica mestiza, no tiene nada que ver con una expresión mestiza. Entre nosotros han existido mestizos que han intentado expresarse dentro de

${ }^{22}$ En los apuntes de una charla que Lezama sostuvo alrededor de 1944 se nota claramente esta dicotomía que va de la fascinación a la distancia crítica respecto de la obra de Valéry: "[era] uno de los últimos representantes de un estilo que convertía al poeta en centro y dominio de un sistema de inmensas coordenadas [...]. Llegaba así Valéry a ser para toda nuestra generación un maestro doblemente venerable. En nuestra adolescencia nos había llenado de inquietud, nos llevaba el paso del tiempo a rendirle el mayor de los homenajes: el de nuestra inconformidad con su obra". "Conversación sobre Paul Valéry" [circa 1944] en Iván González Cruz [ed.], Archivo de José Lezama Lima. Miscelánea, Madrid, Centro de Estudios Ramón Areces, 1998, pp. 368,370 .

23 Lezama Lima, "Coloquio...,", p. 51. 
los cánones del parnasianismo, y gran parte de la poesía afrocubana, en cambio, es de poetas de raza blanca. Se ve que una cosa es el mestizaje y otra abogar por una expresión mestiza. Una expresión mestiza es un eclecticismo artístico que no podrá existir jamás. ${ }^{24}$

El poco aprecio por el movimiento negrista fue característico del núcleo cercano al poeta. En las revistas que Lezama publicaba, algunos de los colaboradores no dejaron de expresar sus opiniones, poco favorables, sobre ese movimiento artístico. José Ardévol, reconocido músico cubano, por ejemplo, escribió en Espuela de Plata, segunda revista dirigida por Lezama:

La creencia que comparten muchos, de que lo "afro-cubano" es la única solución posible de los problemas que en la actualidad tiene planteados el arte cubano, me parece francamente errónea $[. .$.$] hoy lo más sano sería dejar a un lado todo lo$ típico, todo exagerado localismo y exotismo [... ]. Quizá sea interesante advertir que en la poesía cubana el "afrocubanismo" no se ha adueñado de casi todas las voluntades, como en la música, sino que, por el contrario, hay y ha habido siempre en los poetas cubanos un grupo, integrado por algunos de los mejores, que siempre ha considerado al "afrocubanismo" como un fenómeno fundamental temporal, de vida efímera. ${ }^{25}$

A pesar de la crítica al negrismo literario, Lezama publicó en sus revistas colaboraciones de algunos de los miembros de ese movimiento; el desacuerdo estético no significó negación. Emilio Ballagas y Ramón Guirao publicaron algunos poemas en Verbum y Espuela de Plata. ${ }^{26}$ La actitud beligerante de Lezama, en los años treinta, cambió con el paso del tiempo. Varias razones y algunos personajes influyeron en esta transformación. Uno de ellos fue, sin duda, Lydia Ca-

${ }^{24}$ Ibid., p. 57.

${ }^{25}$ José Ardévol, "Agua clara en el caracol del oído", en Espuela de Plata, núm. 1, agosto-septiembre, 1939, p. 10.

${ }^{26}$ Emilio Ballagas, "Soneto sin palabras", en Verbum, núm. 2, julio-agosto, 1937, p. 14; Emilio Ballagas, "Playa", en Espuela de Plata, enero, febrero, marzo, 1940, p. 7; Ramón Guirao, "Soledad", en Espuela de Plata, enero, febrero, marzo, 1940, p. 17. Guirao también publicó un par de textos en prosa en la segunda revista de Lezama, $c f r$. Ramón Guirao, "El tigre, el mono y la venado (fábula Lucimî)", en Espuela de Plata, octubre-noviembre, 1939, s. p.; Ramón Guirao, "Vida de niño", en Espuela de Plata, febrero, 1941, pp. 22-25. 
brera. La escritora cubana, quien había vivido en Francia durante varios años, publicó hacia 1936 en París un libro de cuentos con tema negrista: Contes nègres à Cuba. En 1940, Cabrera regresó a Cuba. Por esa misma época, el pintor Wifredo Lam también volvió a la Isla, después de haber vivido en España y en Francia. Uno de los primeros proyectos que Cabrera y Lam realizaron en conjunto en Cuba fue la traducción y publicación de un poema, que tiempo después sería fundamental para el movimiento de la negritud: Regreso al país natal, del poeta martiniqués Aimé Césaire. ${ }^{27}$ En la década de los cuarenta, Lydia Cabrera comenzó, bajo el ojo crítico y el apoyo de su cuñado, Fernando Ortiz, sus estudios sobre los aspectos religiosos de las comunidades afrocubanas. Al mismo tiempo que realizaba sus investigaciones antropológicas, Cabrera se vinculó con los proyectos editoriales de Lezama. En 1945, por ejemplo, publicó su primera colaboración con la revista Orígenes; el texto era una recreación de mitos y leyendas de las comunidades afrocubanas. ${ }^{28}$ En esa revista, Cabrera dio a conocer varios relatos donde recreó el ambiente mítico y religioso de las tradiciones orales de los afrodescendientes. ${ }^{29}$

María Zambrano escribió un ensayo sobre las fabulaciones poéticas y mitológicas de la antropóloga-escritora. ${ }^{30}$ Años más tarde, cuando Cabrera publicó su gran obra sobre los símbolos religiosos afrocubanos, El monte, la revista Orígenes, y Lezama con ella, no dejó pasar la oportunidad para hablar del libro y publicó una reseña. ${ }^{31}$ Todo el ambiente mito-poético de los trabajos de Cabrera no pasó desapercibido para Lezama. De hecho en 1956, el poeta escribió un ensayo a propósito de un refranero que la escritora acababa de publicar. Ahí, Lezama elogió la figura y los trabajos de la investigadora: "El nombre de Lydia Cabrera está unido para mí a ciertas mágicas asociaciones del iluminismo [...]. El refranero allegado por (ella) [...], tiene la imprescindible nobleza de aclarar el cuestionario que debe situarse en la introducción a nuestra cultura. La sabi-

${ }^{27}$ Aimé Césaire, Regreso al país natal, trad. de Lydia Cabrera, ilus. de Wifredo Lam, La Habana, 1940.

${ }^{28}$ Lydia Cabrera, "La virtud del árbol Dagame", en Orígenes, núm. 7, 1945, pp. 9-18.

${ }^{29}$ Lydia Cabrera, "Jicotea esta noche fresca...", en Orígenes, núm. 9, 1946, pp. 28-31.

${ }^{30}$ María Zambrano, "Lydia Cabrera: poeta de las metamorfosis", en Orígenes, núm. 25, 1950.

${ }^{31}$ Francis Miomandre, "Sobre El monte de Lydia Cabrera", en Orígenes, núm. 39, 1955. 
duría de los dioses debe espejear en la de los efímeros", ${ }^{32}$ Es indudable que el poeta, bajo el influjo de la antropóloga, se acercó al universo religioso afrocubano, sobre todo a partir de los años cincuenta. La inclusión, en 1957, del artista mulato Aleijadinho y su barroco afroamericano en La expresión americana debería leerse en ese contexto.

Para los años sesenta, cuando Lezama comienza a idear esa especie de historia de la imaginación de la humanidad, que él llamó "Las eras imaginarias", las culturas afrodescendientes ya habían tomado un papel importante en su obra. En 1964, por ejemplo, en un ensayo aparecido en su libro La cantidad hechizada, Lezama aseguraba, sobre los antecedentes de la poesía negra:

Hemos situado a Bartolomé José Crespo, que firmaba con el seudónimo de Creto Gangá entre los poetas populistas, como precursor de la poesía negra. Se publica también una colección de cantos negros anónimos, porque aclaran, en su raíz puramente popular, las zonas de nuestra sensibilidad. Es una poesía ritual, mágica, a veces de simples exorcismos, pero que va pasando a la gran síntesis etnográfica y sensible de nuestro país. Ya esa poesía popular negra aparece estrechamente unida a la música negra. Está acompañada de un ritmo, la música y la poesía se entrelazan en tal forma que sus contornos se borran. ${ }^{33}$

Las críticas amargas de los años treinta habían pasado a la historia. Con el transcurso de las décadas, el aporte de la poesía negra ya era visto por Lezama como un elemento propio de la sensibilidad de la Isla. El poeta, para esos momentos, hacía un balance más mesurado sobre los aportes africanos a la cultura nacional. Unos cuantos años después, en 1968, Lezama trató una figura fundamental para las comunidades negras del Caribe. El personaje había aparecido en varios relatos de Lydia Cabrera. Se trataba de "El taita", el viejo sabio y esclavo que aconseja. En el pasaje al que me refiero se combinan dos aspectos. Por un lado, la idea de saber sobre la vida (en el sentido que lo utiliza Ottmar Ette) con una práctica comunitaria cubana y, por el otro, la definición de la cultura afroa-

32 José Lezama Lima, "Lydia Cabrera", [1956], en Obras completas II, México, Aguilar, 1977.

33 González Cruz, Diccionario ..., p. 411. 
mericana como fuente de sabiduría nacional, en el vínculo con la mayor figura de la Isla: José Martí. En estas páginas lezamianas encontramos un concentrado almacén de saberes sobre el vivir:

En Cuba solamente ha sido alcanzada la sabiduría por el taita, el negro esclavo al llegar a su ancianidad, y [por] [... J José Martí. Estos estilos de sabiduría surgen del hombre que se desenvolvió en circunstancias extremadamente hostiles y de muy difícil desciframiento [...]. Cuando se llega a ser un taita, se ha sufrido mucho desde la niñez [.. . ]. En sus ochenta años, el taita irradia como un monarca [...]. Aconseja, da la receta para cortar la fiebre y une el destino de los enamorados. Señala la llegada de las lluvias y el peligro por la calcinación por el rayo. Conoce el zumbido de la cañada del río y el relincho peculiar del caballo cuando se acerca enmascarado el ciclón. Señala la mañana para la recogida del sembradío y la de la maldición en la estación estéril. Dice la sentencia hermosa como una canción y el plañido para acompañar la caducidad inevitable. El que se le acerca siente que vuelve a nacer y oye en sus dictados a la pitia délfica que nos repite que lo bello es lo más justo y la salud lo mejor. El taita vive en una cabaña, apartado, con pequeños animales graciosos [...]. Dice la palabra de prudencia o inicia la gran rebeldía. Es un rey, un sabio, un hechicero, cuando muere parece como si un toro benévolo se lo llevase de paseo a la región de los lagos [.. . ]. La sabiduría del taita es la que ya Martí atesora en su diario. ${ }^{34}$

Sin embargo, el proceso de apropiación e integración de la cultura afrocubana en la obra de Lezama Lima culmina, hacia finales de los sesenta y principios de los setenta, en la representación de Ynaca Eco Licario, una de las figuras importantes de sus dos novelas. Lezama, en la conformación de este personaje, traslapa diversos estratos míticos: etruscos, griegos, romanos, católicos. Sin embargo, hay un sustrato o capa, en el sentido arqueológico del término, que todavía no se ha desvelado del todo. Ynaca, en varios aspectos, remite al universo simbólico de Yemayá, la diosa del mar y de la fertilidad en el panteón Yoruba de la santería cubana. ${ }^{35}$

34 José Lezama Lima, "La pintura y la poesía en Cuba (siglos xVIII y xIX)" [1966], en Obras completas II, México, Aguilar, 1977, pp. 969 y 970.

35 Sobre el universo religioso de la santería la obra lezamiana puede revisarse, aunque con cierta cautela pues hay generalizaciones que pueden ser discutibles: Alicia E. Badillo, "La santería 
En el último capítulo de la novela Paradiso vemos a José Cemí asistir a los funerales de su antiguo amigo y maestro: Oppiano Licario. Ahí, Cemí ve por primera vez a Ynaca, la hermana del difunto. El lugar donde se encuentran es una funeraria con un decorado peculiar; en las columnas de la fachada se observan calamares, pulpos y reminiscencias acuáticas. ${ }^{36}$ En el universo de la santería, los orishas, o deidades, se vinculan a faunas específicas. Yemayá, al ser la diosa del mar, se relaciona con los animales marinos. Este dato parecería intrascendente si no se apoyara en otros elementos de la narrativa posterior de Lezama. Hay que tener en cuenta que la escena del funeral de Oppiano fue escrita justo antes de que Lezama diera a publicar la novela en 1966. En los años que vinieron, el poeta comenzó la redacción de otro libro que sería la continuidad de Paradiso. En 1976, a la muerte de Lezama, el relato todavía estaba inconcluso y así fue dado a las imprentas de La Habana y de la ciudad de México. Dos ediciones casi simultáneas aparecieron en Cuba y en México. ${ }^{37}$ La novela llevó por título Oppiano Licario. En las páginas de ese libro vuelve a aparecer Ynaca Eco Licario con más elementos asociados a la deidad Yoruba. Una característica de la santería cubana es que las deidades u orishas son representados de forma metonímica con atributos u objetos. Los atributos pueden ser colores, collares, comidas o artículos asociados a su culto. El color azul, en este caso, es un atributo de la diosa Yemayá. En el capítulo quinto de Oppiano Licario, Cemí busca a Ynaca para hablar con ella. Primero va a casa del amigo muerto, después a la funeraria donde la había visto por última vez. En ninguno de los dos lugares la encuentra. De forma paralela, Ynaca busca a Cemí en la biblioteca del Castillo de la Fuerza. Ambos están en los lugares equivocados. La búsqueda infructuosa se resuelve al día siguiente cuando los dos se encuentran en la puerta del Castillo de la

como base epistemológica de algunos personajes homoeróticos en Paradiso", en Exégesis, Revista de la Universidad de Puerto Rico en Humacao, núm. 41, 2001, pp. 53-60.

36 "En lo alto de las columnas chorreaban calamares, los que se retorcían a cada interpretación marina para receptar los consejos lunares [...]. Una mezcla de pulpo y estalactita trepaba por aquellas columnas inundadas de reflejos plateados". José Lezama Lima, Paradiso [1966], Cintio Vitier [ed.], México, Archivos unesco, 1988, p. 455.

37 José Lezama Lima, Oppiano Licario, La Habana, Arte y Literatura, 1977; José Lezama Lima, Oppiano Licario, México, Era, 1977. 
Fuerza. La descripción que Lezama hace de Ynaca es muy significativa: "venía cubierta con telas de color tan transparente que a Cemí le recordaron los colores que aparecen en algunos retratos de Gaingsborough [...] La falda era de un azul muy atenuado y la blusa blanca con encajillos cremosos" ${ }^{38}$ Los colores que Ynaca viste pasarían desapercibidos si no fuera porque Lezama es muy poco afecto a la descripción de las ropas de sus personajes y porque ese azul se vuelve a repetir páginas más adelante: "Ya en la biblioteca (Cemî) divisó a Ynaca Eco acostada en un anchuroso sofá de mimbre. Cubría su cuerpo con una azulosa seda oscura que se doblaba a la manera del Hymation griego" ${ }^{39}$ Resulta significativo que el color designado para Yemayá, deidad marina, sea el azul.

Pero volvamos al momento en el que se encuentran Ynaca y Cemí a las puertas del Castillo de la Fuerza. Ynaca comenta el desencuentro del día anterior con las siguientes palabras: "Yo lo hubiera esperado en la torre donde Isabel esperaba la llegada fantasmal de Hernando de Soto - dijo Ynaca entre abriendo su sonrisa-ayer lo estuve esperando, acompañándolo hasta que se interpusieron las piedras. ${ }^{140} \mathrm{La}$ última frase de Ynaca, enigmática e indescifrable, es comentada por el narrador: "aquel 'se interpusieron las piedras' alcanzó una vibración no previsible, como si hubieran chocado dos longitudes de ondas separadas por una clavija de metal transparente". ${ }^{41}$ Páginas después, en otro encuentro con ella, Cemí vuelve a recordar la sentencia y dice algo que nos devela el sentido de la oración: "Me gustaría que tironeásemos la primera expresión que le oí cuando nos encontramos en el puente del Castillo de la Fuerza -comenzó diciendo Cemí-: yo lo hubiera encontrado si no se interpusieran las piedras. Podía quedar en su simple potencia oracular, como dicha por un babalao reglano o por una pitia délfica." ${ }^{32}$ La relación entre algún personaje lezamiano y una pitia délfica no es nueva. Varios de ellos en algún momento son asociados a la sacerdotisa griega. Lo nuevo y significativo es el vínculo de Ynaca con un babalao reglano.

\footnotetext{
${ }^{38}$ Ibid., p. 117.

${ }^{39}$ Ibid., p. 150.

${ }^{40}$ Ibid., p. 117.

${ }^{41}$ Ibid., pp. 117 y 118.

${ }^{42}$ Ibid., p. 128
} 
Los babalaos son los curanderos y adivinadores de los ritos de la santería. Pero lo más significativo es que, en el panteón sincrético de la santería, donde cada orisha se asocia con un santo católico, la virgen de Regla es Yemayá. Un babalao reglano es, entonces, un sacerdote de Yemayá. La identificación entre Ynaca y la deidad se vuelve más evidente. Además, hay que tomar en cuenta que las piedras son un elemento muy importante en los ritos afrocubanos; las piedras poseen, en ese imaginario religioso, fuerzas sobrenaturales. Por eso Ynaca asegura, como un babalo reglano, que las piedras se interpusieron para que no se encontrara con José Cemí. Un último episodio refuerza los lazos entre la deidad Yoruba y el personaje de Lezama.

En el capítulo seis, después de haberse encontrado en el Castillo de la Fuerza, Ynaca invita a Cemí a que la visite en su casa. La hermana de Oppiano escribe un enigmático mensaje lleno de símbolos que de alguna u otra manera se asocian a la deidad del mar. Sin embargo, eso no es lo más importante. Lo significativo en este apartado es el ambiente en el cual se recrea ese encuentro. Cemí atraviesa La Habana en medio del inicio de un huracán. La ciudad se prepara para recibir al dios irritado. Cemí llega a casa de Ynaca; la encuentra desnuda, cubierta tan sólo con un manto azul. El anuncio de un encuentro erótico se prepara. Ynaca oficia un complejo rito en torno a Cemí: quema sus ropas, dibuja signos cabalísticos, rocía sus genitales con un líquido, traza un círculo. Toda la escenificación tiene una finalidad muy clara: Ynaca quiere quedar embarazada de Cemí. La representación de este rito de fertilidad, en medio de los anuncios de un huracán, recuerda que Yemayá es la diosa madre de todos los orishas y que además es la reina del mar y de la fertilidad.

Con Ynaca Eco Licario pasamos, así, a la integración del universo mitológico afroamericano a la creación literaria de Lezama. El trayecto cumple entonces un ciclo: va de la negación de la poesía negrista, en los años treinta, a la integración del universo mito-poético afrocubano en los años sesenta y setenta. En ese periplo, Lezama traza un proceso de asimilación cultural. Lo que propicia ese tránsito es la propia concepción del barroco en Lezama que permite una convivencia constante, compleja, asimétrica y devoradora, de universos que en otros tiempos y en otros lugares serían impensables. El cuarto de Lezama, con 
SeRgIo Ugalde QuinTANA

su decorado abigarrado y exuberante, no sólo es un amontonamiento de objetos, libros y textos, sino el laboratorio de una convivencia cultural, el espacio del aprendizaje de una sensibilidad múltiple y voraz que podría quedar caracterizado por una de sus propias frases: "el gozo del ciempiés es la encrucijada".

Recibido: 22 de agosto, 2011.

Aceptado: 14 de septiembre, 2011. 